Original Research

\title{
Study of the Clogging Properties of Mixed Leachate
}

\author{
Mingde Xie ${ }^{1,2 *}$, Dan Liu', Yiming Tang¹, Mei Feng ${ }^{1}$, Xiaoying Yi ${ }^{1}$ \\ ${ }^{1}$ Faculty of Geosciences and Environmental Engineering, Southwest Jiaotong University, Chengdu, P.R. China \\ ${ }^{2}$ School of Life Science and Engineering, Southwest Jiaotong University, Chengdu, P.R. China
}

Received: 12 October 2019

Accepted: 15 November 2019

\begin{abstract}
The preferential flow of leachate in landfill is unavoidable. Therefore, the mixed leachate formed by mixing young leachate and old leachate is the form of leachate mainly present in the gravel layer. In this study, static anaerobic culture experiments were used to investigate the changes in the properties of the mixed leachate. During the experiment, the chemical oxygen demand (COD) content of the three mixed leachates decreased greatly; CODs of $10 \%, 20 \%$, and $30 \%$ were reduced by $12 \%, 38 \%$, and $24 \%$, respectively. The concentrations of $\mathrm{Ca}^{2+}$ and $\mathrm{Mg}^{2+}$ also decreased; $\mathrm{Ca}^{2+}$ was significantly reduced after a short time. The $\mathrm{pH}$ also dropped. The oxidation-reduction potential (ORP) of the three mixed leachates increased, indicating that the reducing organic matter in the leachate was gradually decomposed by microbial oxidation. Analysis by X-ray diffraction (XRD) showed that the main inorganic precipitate is magnesium-containing calcite, an isomorphous crystal. Studies have shown that if there is a mixed leachate in the gravel layer, severe clogging occurs therein. The clogging material is mainly a magnesium-containing calcite precipitate formed by the metabolic activity of organic matter in the microbial degradation of mixed leachate. Some suggestions were made for the operation and management of landfills.
\end{abstract}

Keywords: anaerobic culture, clogging, magnesium-containing calcite, mixed leachate, operation management

\section{Introduction}

In China, sanitary landfills are one of the methods for municipal solid waste (MSW) disposal [1]. In a running landfill, the collected waste is landfilled in layers in a landfill unit according to landfill operation procedures. Microorganisms catabolize organic components of the landfill waste. In the unit, the decomposition of the filled waste goes through five phases: initial adjustment, transition, acidification,

*e-mail: mingdexie@ swjtu.edu.cn methane fermentation, and stationary phase [2]. The earliest filled waste at the bottom of the unit is generally in the methane fermentation and stationary phases, while the newly filled waste in the upper part is in the acidic phase [3].

The landfill waste contains moisture, and the organic components subjected to microbial decomposition produce additional water; hence, the waste body has high moisture content [4]. Leachate forms when the moisture content of the waste exceeds its field capacity. Leachate is a high-concentration organic wastewater with complex composition [5-7]. In order to prevent the leachate from polluting the groundwater and the environment, a leachate collection system (LCS) 
consisting of gravel drainage layer and perforated drainage pipes is installed at the bottom of the sanitary landfill to discharge the leachate [8]. Because of biological, chemical, and physical effects, the leachate forms solids when flowing through the LCS. The solids include biofilm [9], inorganic precipitates (mainly $\mathrm{CaCO}_{3}(\mathrm{~s})$ ) [10], and trapped suspended solids (SS) [11]. These solids deposit in the voids of the gravel drainage layer, causing clogging which leads to a reduced LCS service life [12].

The young leachate produced by the newly filled waste has high COD content, a $\mathrm{pH}$ of $<7.0$, and high content of $\mathrm{Ca}^{2+}$ and $\mathrm{Mg}^{2+}$ [13-14]. The old leachate produced in the earlier filled waste has lower COD content, lower $\mathrm{Ca}^{2+}$ and $\mathrm{Mg}^{2+}$ content, and a $\mathrm{pH}>7.0$ [15]. Because of the higher content of COD and $\mathrm{Ca}^{2+}$ in the young leachate, more biological clogging (biofilm) and chemical clogging $\left(\mathrm{CaCO}_{3}(\mathrm{~s})\right)$ occurs [16]. The old leachate with lower content of $\mathrm{COD}$ and $\mathrm{Ca}^{2+}$ causes less clogging when it flows through the gravel layer [15-16]. At the base of the landfill unit, the earliest filled waste is in the methane fermentation and stationary phases and rich in methanogenic microorganisms, which decomposes the COD in the young leachate from the upper layer and produces landfill gas (LFG) (mainly $\mathrm{CH}_{4}(\mathrm{~g})$ and $\mathrm{CO}_{2}(\mathrm{~g})$ ) [17-18]. The carbonate $\left(\mathrm{CO}_{3}{ }^{2-}\right)$ ionized by $\mathrm{CO}_{2}(\mathrm{aq})$ reacts with $\mathrm{Ca}^{2+}$ in the leachate to form $\mathrm{CaCO}_{3}(\mathrm{~s})$, which causes an increase in the $\mathrm{pH}$ of the young leachate and a decrease in the biochemical oxygen demand (BOD) and $\mathrm{Ca}^{2+}$ content [19]. The properties of the young leachate are converted into those of the old leachate. When it enters the LCS, the leachate forms less precipitate and thus no longer causes clogging.

The young leachate in the running landfill is continuously produced in the newly filled waste. The landfill waste has porosity heterogeneity, which means the waste body has preferential flow channels [20-24]. These shorten the leachate drainage path and the hydraulic retention time (HRT) in the methanogenic waste layer, so that the young leachate from the new waste flows into the LCS and mixes with the old leachate [15]. Hence, the leachate existing in the LCS is actually a mixture of young and old leachate [25].

The mixed leachate has the properties of young and old leachate. The content of COD and $\mathrm{Ca}^{2+}$ is high, because the $\mathrm{pH}$ of the mixed leachate is generally $>7.0$, the volatile fatty acids (VFAs) are mostly in an ionic form, and the acid/base buffer system formed by VFAs in the leachate collapses [26].

Previous studies on the clogging of leachate in the gravel drainage layer found that most of the leachate used was leachate that had flowed through the gravel drainage layer or synthetic leachate [27-29]. The COD, $\mathrm{Ca}^{2+}$, and $\mathrm{Mg}^{2+}$ of this leachate have been treated using the microbial membrane of the gravel drainage layer, and the properties of the leachate have been found to change greatly [30]. Therefore, this does not accurately reflect the changes in properties of leachate flowing through the gravel layer.

In this study, the mixed leachates formed by the mixture of young and old leachate were used as the research target, and a static anaerobic culture experiment was used to investigate the change in properties of the mixed leachate. The main indicators were $\mathrm{COD}, \mathrm{Ca}^{2+}, \mathrm{Mg}^{2+}, \mathrm{pH}$, ORP, and the composition of the formed solid. Our aim was to thoroughly study the changes in leachate properties of the gravel layer and to provide guidance and recommendations for the operational management of the landfill to control the clogging of the gravel layer. This work is part of a series of studies on the clogging of leachate in the gravel drainage layer.

\section{Material and Methods}

\section{Materials}

The leachate used in the experiment was a mixed leachate formed by the young leachate from a laboratory-filled MSW, and the old leachate was taken from a sanitary landfill leachate conditioning pool in Chengdu, China. The properties of the young and old leachate are shown in Table 1. The current landfill is generally a large landfill with a running period of more than 10 years and a landfill height of several tens of meters [31]. From the perspective of the entire operational period of the landfill, the proportion of old leachate is relatively large, and the proportion of young leachate flowing through the preferential flow channel to the gravel layer is not too high [23]. In order to better analyze the difference in properties of different ratios of mixed leachate under anaerobic culture, mixed leachates containing $10 \%, 20 \%$, and $30 \%$ young leachate were prepared. The proportion of the young and old leachate is shown in Table 2, and the properties of the mixed leachate are shown in Table 3.

\section{Experimental Design and Operation}

The experimental device custom-built in the laboratory consists of an anaerobic culture flask equipped with a balance gas bag and a sampling tube (Fig. 1).

Table 1. Properties of young and old leachates.

\begin{tabular}{|c|c|c|}
\hline Parameters & Young leachate & Old leachate \\
\hline $\mathrm{COD}(\mathrm{mg} / \mathrm{L})$ & 43542 & 16208 \\
\hline $\mathrm{Ca}^{2+}(\mathrm{mg} / \mathrm{L})$ & 4966 & 578 \\
\hline $\mathrm{Mg}^{2+}(\mathrm{mg} / \mathrm{L})$ & 319 & 159 \\
\hline $\mathrm{pH}$ & 6.19 & 8.72 \\
\hline $\mathrm{ORP}(\mathrm{mV})$ & 128 & -300 \\
\hline
\end{tabular}


Table 2. Proportion of young and old leachates in mixed leachate.

\begin{tabular}{|c|c|c|c|c|}
\hline No. & $\begin{array}{c}\text { Young } \\
\text { leachate (\%) }\end{array}$ & $\begin{array}{c}\text { Total } \\
\text { volume } \\
(\mathrm{ml})\end{array}$ & $\begin{array}{c}\text { Young } \\
\text { leachate } \\
(\mathrm{ml})\end{array}$ & $\begin{array}{c}\text { Old } \\
\text { eachate } \\
(\mathrm{ml})\end{array}$ \\
\hline 1 & 10 & 450 & 45 & 405 \\
\hline 2 & 20 & 450 & 90 & 360 \\
\hline 3 & 30 & 450 & 135 & 315 \\
\hline
\end{tabular}

Table 3. Properties of mixed leachate

\begin{tabular}{|c|c|c|c|}
\hline Parameters & $10 \%$ & $20 \%$ & $30 \%$ \\
\hline $\mathrm{COD}(\mathrm{mg} / \mathrm{L})$ & 19782 & 24136 & 26411 \\
\hline VFAs $(\mathrm{mg} / \mathrm{L})$ & 2892 & 4656 & 6216 \\
\hline $\mathrm{Ca}^{2+}(\mathrm{mg} / \mathrm{L})$ & 685 & 1077 & 1337 \\
\hline $\mathrm{Mg}^{2+}(\mathrm{mg} / \mathrm{L})$ & 191 & 205 & 222 \\
\hline $\mathrm{NH}_{3}-\mathrm{N}(\mathrm{mg} / \mathrm{L})$ & 1588 & 1642 & 1681 \\
\hline $\mathrm{pH}$ & 8.70 & 8.55 & 8.58 \\
\hline $\mathrm{ORP}(\mathrm{mV})$ & -320 & -323 & -312 \\
\hline
\end{tabular}

The volume of the anaerobic flask was $500 \mathrm{ml}$. At the start of the experiment, $450 \mathrm{ml}$ of the mixed leachate was charged. In order to maintain the anaerobic state, the upper air was removed using $\mathrm{N}_{2}(\mathrm{~g})$, and the anaerobic flask was sealed by a cap with a Teflon gasket. Two needles of different lengths were inserted into the anaerobic flask. The long needle was inserted into the leachate and connected to the bolt through the soft rubber tube. This was used for taking leachate samples. Normally, the soft rubber tube is clamped by the butterfly clip for sealing. The short needle was not inserted under the liquid surface, but was instead connected to the balance bag by a soft hose, and a small volume of $\mathrm{N}_{2}(\mathrm{~g})$ was placed in the balance bag to prevent air from entering during sampling.

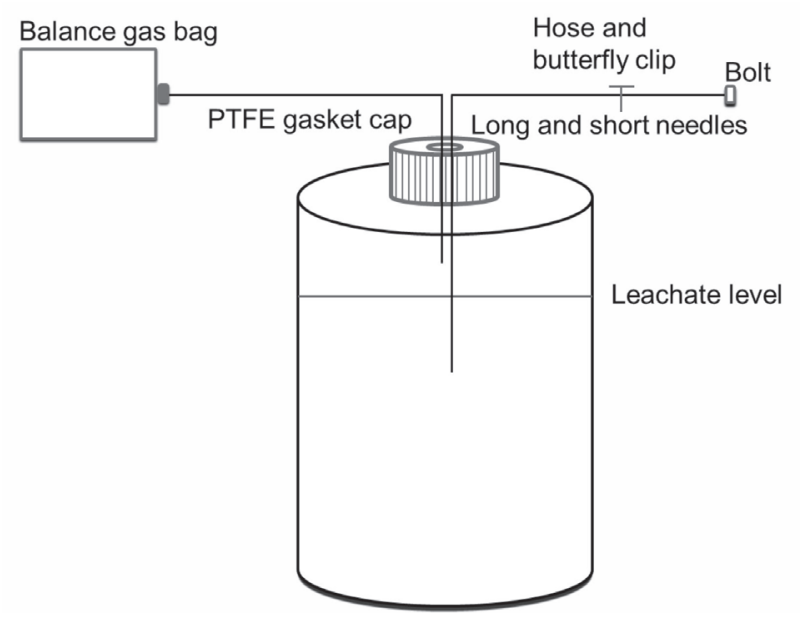

Fig. 1. Schematic of the static anaerobic flask structure (not to scale).
In the landfill, microbial decomposition of organic matter in the waste releases heat and raises the temperature of the waste and leachate. The internal temperature of the landfill can be as high as $60-90^{\circ} \mathrm{C}$ [32]. In general, the medium temperature range of the landfill is between 34 and $45^{\circ} \mathrm{C}$, which is the most conducive to microbial decomposition of organic matter in the waste and the generation of landfill gas [33]. The main microorganism that decomposes organic matter in waste and produces landfill gas is anaerobic methanogenic bacteria. The $35^{\circ} \mathrm{C}$ is one of the optimum growth temperatures for mesophilic methanogens [34]. In order to carry out the experiment better, we set the experimental temperature to about $35^{\circ} \mathrm{C}$. Static anaerobic culture was carried out in a constanttemperature incubator with the temperature controlled at $35 \pm 1^{\circ} \mathrm{C}$. The samples were analyzed once a week. The analytical indicators were $\mathrm{COD}, \mathrm{Ca}^{2+}, \mathrm{Mg}^{2+}, \mathrm{pH}$, and ORP. At the end of the experiment, the solid at the bottom of the anaerobic flask was taken for analysis of its sediment properties.

\section{Measuring Indices and Methods}

COD was determined by the potassium dichromate digestion method. The $\mathrm{Ca}^{2+}$ and $\mathrm{Mg}^{2+}$ were determined using a Hitachi Z-5000 atomic absorption spectrometer after digestion with perchloric acid and nitric acid. The $\mathrm{pH}$ and ORP were determined by a $\mathrm{pHS}-3 \mathrm{C} \mathrm{pH}$ meter. The water content and organic and inorganic components of the precipitate were determined by evaporation in a $105^{\circ} \mathrm{C}$ oven and a $550^{\circ} \mathrm{C}$ muffle furnace to constant weight [11]. The volatile fatty acids (VFAs) and ammonia nitrogen $\left(\mathrm{NH}_{3}-\mathrm{N}\right)$ of the mixed leachate were determined by distillation and acid-base titration. A Panalytical Empyrean X-ray diffractometer was used to analyze material composition of the solid.

\section{Results and Discussion}

\section{Composition of Solids}

The solid at the bottom of the anaerobic flask was yellowish brown. Diluted hydrochloric acid was added to the solids to produce a large number of odorless bubbles. The generated gas was detected using a wet lead acetate test paper, and the test paper did not change color, indicating that the generated gas contained no $\mathrm{H}_{2} \mathrm{~S}(\mathrm{~g})$. The basic properties of the solids obtained from the three mixed leachates are shown in Table 4.

Analyses showed that the solids contained high proportions of $\mathrm{Ca}^{2+}$ and $\mathrm{Mg}^{2+}$ carbonate precipitates. With the increase of young leachate content in the mixed leachate, the $\mathrm{Ca}^{2+}$ content in the leachate gradually increased, the VFAs content also increased, and the biodegradability of the mixed leachate became better, which would produce more $\mathrm{CO}_{3}{ }^{2-}$ and cations reacting to form carbonate precipitates [16]. The biofilm 
Table 4. Basic properties of the solids.

\begin{tabular}{|c|c|c|c|}
\hline Parameters & $10 \%$ & $20 \%$ & $30 \%$ \\
\hline Moisture content (\%) & 87.34 & 70.60 & 61.53 \\
\hline Organic matter (\%) & 24.12 & 18.88 & 21.39 \\
\hline Inorganic matter (\%) & 75.88 & 81.12 & 78.61 \\
\hline $\mathrm{Ca}^{2+}(\%)$ & 24.14 & 26.77 & 28.29 \\
\hline $\mathrm{Mg}^{2+}(\%)$ & 4.00 & 3.25 & 2.81 \\
\hline Dominant inorganic precipitates & $\mathrm{Ca}_{5.4} \mathrm{Mg}_{0.6} \mathrm{C}_{6.00} \mathrm{O}_{18.00} \mathrm{SiO}_{2}$ & $\left(\mathrm{Mg}_{0.1} \mathrm{Ca}_{0.9}\right) \mathrm{CO}_{3} \mathrm{SiO}_{2}$ & $\left(\mathrm{Mg}_{0.06} \mathrm{Ca}_{0.94}\right) \mathrm{CO}_{3} \mathrm{SiO}_{2}$ \\
\hline
\end{tabular}

formed by the anaerobic microbial flora at the bottom of the bottle has a dynamic equilibrium property, and the content remains relatively constant [9]. The density of carbonate precipitation is much greater than that of biofilm. Therefore, the moisture content in the precipitated solids decreased with the increase of young leachate content; the $\mathrm{Ca}^{2+}$ content increased gradually, and the $\mathrm{Mg}^{2+}$ content gradually decreased in the solids. XRD analysis of the solids (Figs 2-4) showed that the dominant inorganic substances in the solids (dry mass) were magnesium-containing calcite and silica $\left(\mathrm{SiO}_{2}\right)$.

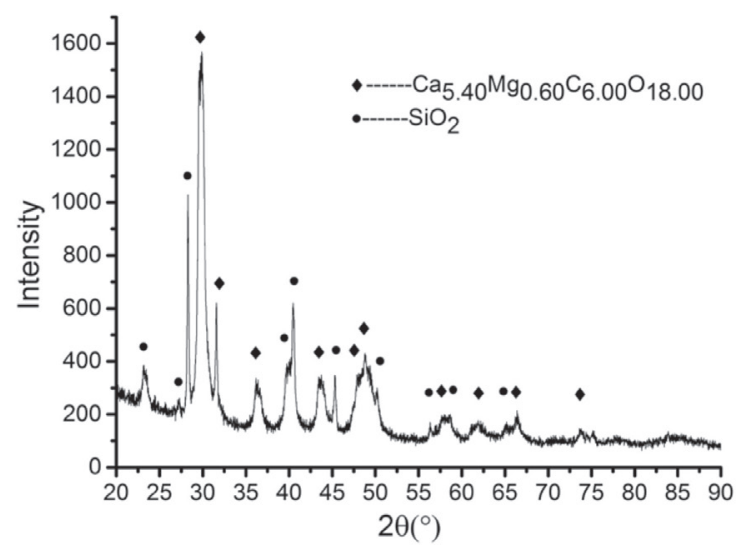

Fig. 2. XRD analysis of the $10 \%$ mixed leachate solid.

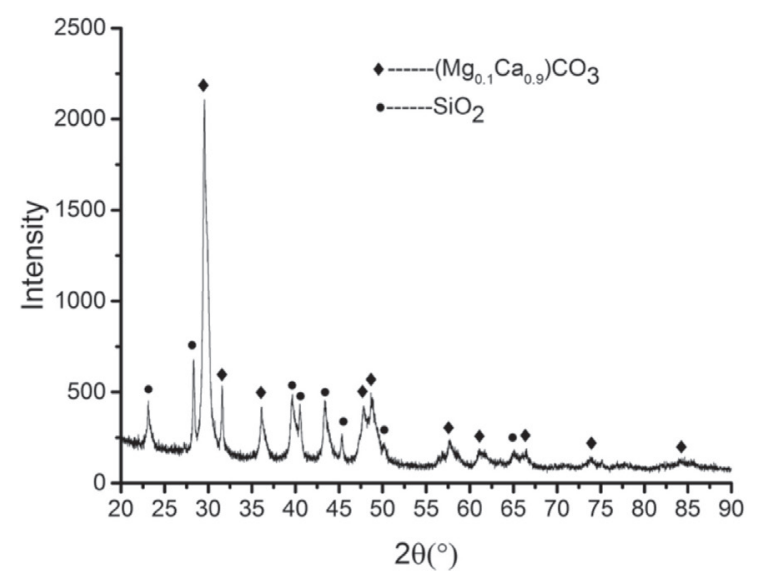

Fig. 3. XRD analysis of the $20 \%$ mixed leachate solid.
With an increase in the content of young leachate in the mixed leachate, the content of $\mathrm{Ca}^{2+}$ in the magnesiumcontaining calcite increased and the content of $\mathrm{Mg}^{2+}$ decreased. The proportion of $\mathrm{SiO}_{2}$ in the solids gradually decreased.

Therefore, if the landfill waste contains more preferential flow channels, more young leachate flows into the gravel layer and forms a mixed leachate with the old leachate, which will cause more chemical deposits to form in the gravel layer $\left(\mathrm{Ca}^{2+}\right.$ and $\mathrm{Mg}^{2+}$ carbonate precipitates ), causing clogging of the LCS.

Magnesium-containing calcite is a compound in which a part of $\mathrm{Ca}^{2+}$ in the crystal lattice is substituted with $\mathrm{Mg}^{2+}$ in the process of crystal formation of calcite [35-36]. $\mathrm{Ca}^{2+}$ and $\mathrm{Mg}^{2+}$ are the same type of cations, both of which tend to form a compound crystal with $\mathrm{CO}_{3}{ }^{2-}$, and the solubility product of $\mathrm{CaCO}_{3}$ is less than that of $\mathrm{MgCO}_{3}$. In the mixed leachate, the $\mathrm{Ca}^{2+}$ content was much higher than that of the $\mathrm{Mg}^{2+}$, but the $\mathrm{Mg}^{2+}$ content was also high; therefore, when $\mathrm{Ca}^{2+}$ and $\mathrm{CO}_{3}{ }^{2-}$ formed a crystal precipitate, some $\mathrm{Mg}^{2+}$ formed a magnesium-containing calcite. In the mixed leachate, the $\mathrm{Ca}^{2+}$ content increased relative to the $\mathrm{Mg}^{2+}$ as the young leachate content increased, so in the formed magnesium-containing calcite, the $\mathrm{Ca}^{2+}$ content increased and the $\mathrm{Mg}^{2+}$ content decreased.

$\mathrm{SiO}_{2}$ is mainly formed by the deposition of inorganic substances contained in sand and silt particles suspended in the leachate [37]. In the mixed leachate,

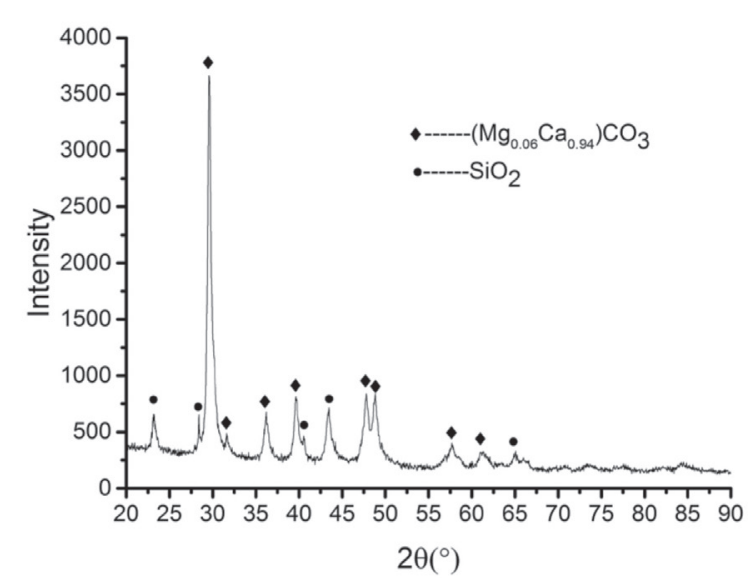

Fig. 4. XRD analysis of the $30 \%$ mixed leachate solid. 
the $\mathrm{Ca}^{2+}$ content and the biodegradability of the leachate increased as the young leachate content increased, thus favoring the formation of carbonate precipitate. The proportion of carbonate precipitate in the solid component increased, and the proportion of $\mathrm{SiO}_{2}$ in the precipitates gradually decreased.

\section{Analysis of COD Change of Mixed Leachates with Elapsed Time}

During the static anaerobic culture period, the COD of the three mixed leachates decreased (Fig. 5), particularly in the $20 \%$ and $30 \%$ mixed leachates; the COD reduction rates were $38 \%$ and $24 \%$, respectively. The $10 \%$ mixed leachate was reduced less, at $12 \%$.

This was because the $20 \%$ and $30 \%$ mixed leachates contained more COD, and the biodegradability was better than that of the $10 \%$ mixed leachate. This was due to higher levels of anaerobic microbial activity, which lead to more COD degradation and higher production of LFG. Therefore, in the operation of the landfill, it is necessary to control the formation of the preferential flow channels and the preferential flow of the leachate as much as possible. Otherwise, serious biological clogging (biofilm) and its accompanying chemical clogging $\left(\mathrm{CaCO}_{3}(\mathrm{~s})\right)$ may form in the gravel layer during long-term operation of the landfill. There was a sudden increase in COD content at one point (28 days of the experiment) in the $20 \%$ and $30 \%$ mixed leachates. This may be due to the high microbial content in the mixed leachate during the static anaerobic culture period. The microorganisms were suspended in the leachate, and some may have adhered to the sampled needle, which may have led to a high COD measurement.

\section{Analysis of $\mathrm{Ca}^{2+}$ Change in the Mixed Leachates with Elapsed Time}

The $\mathrm{Ca}^{2+}$ content of the three mixed leachates was greatly reduced after a short time (within the first measurement period; Fig. 6). The mixed leachate had

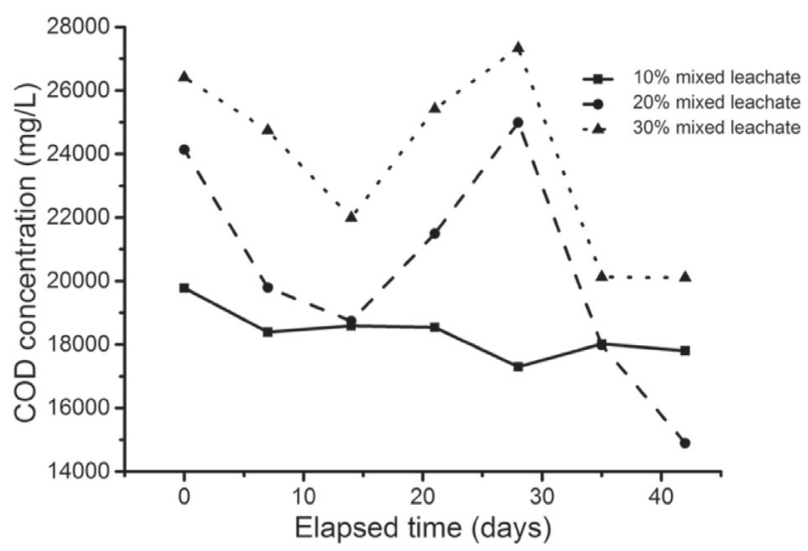

Fig. 5. Variation in COD of the mixed leachates versus elapsed time. a high $\mathrm{Ca}^{2+}$ content (Table 3). The $\mathrm{pH}$ of the mixed leachate was alkaline and the $\mathrm{CO}_{2}(\mathrm{aq})$ produced by the microbial decomposition of organic matter in the leachate was ionized into $\mathrm{CO}_{3}{ }^{2-}$, which reacted with the $\mathrm{Ca}^{2+}$ at high concentration in the mixed leachate to form carbonate precipitate.

Because of the higher $\mathrm{Ca}^{2+}$ content, especially in the $20 \%$ and $30 \%$ mixed leachates, and the greater biodegradability of the leachate, microbial decomposition of organic matter in the leachate after a short time produced more $\mathrm{CO}_{3}{ }^{2-}$, which reacted with $\mathrm{Ca}^{2+}$ in the leachate to form carbonate precipitate. Therefore, the content of $\mathrm{Ca}^{2+}$ in the $20 \%$ and $30 \%$ mixed leachate decreased more. If the young leachate in the upper layers of the landfill flows into the gravel drainage layer through a preferential flow channel and forms a mixed leachate with the old leachate, more carbonate precipitate forms in a shorter time. The insoluble carbonate is deposited in the voids of the gravel drainage layer, which reduces the drainable porosity and hydraulic conductivity of the gravel drainage layer and causes clogging in the long term.

How to prevent and avoid preferential flow in landfills is a consideration for landfill managers and researchers, although maintaining the unsaturation of the gravel drainage layer to reduce the HRT of the leachate can reduce the degree of clogging of the gravel drainage layer [38]. However, if there is preferential flow of the young leachate to the gravel drainage layer, chemical precipitate forms in it, especially near the perforated collection pipes, and it more easily leads to clogging [39-40]. Therefore, under the premise of improving the performance of the anti-seepage layer, the leachate level of the gravel layer is appropriately increased, and the supersaturation state of the gravel layer is maintained to avoid the preferential flow of the young leachate [15]. Hence, the young leachate completely decomposes in the methanogenic phase waste, the properties are stable, and no obvious clogging occurs during flow through the gravel layer. It is an alternative way to operate the landfill.

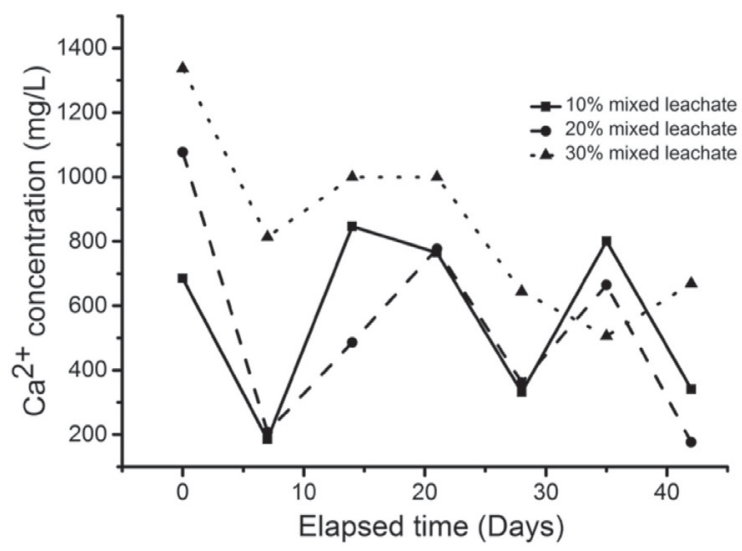

Fig. 6. Variation in $\mathrm{Ca}^{2+}$ content in mixed leachates versus elapsed time. 


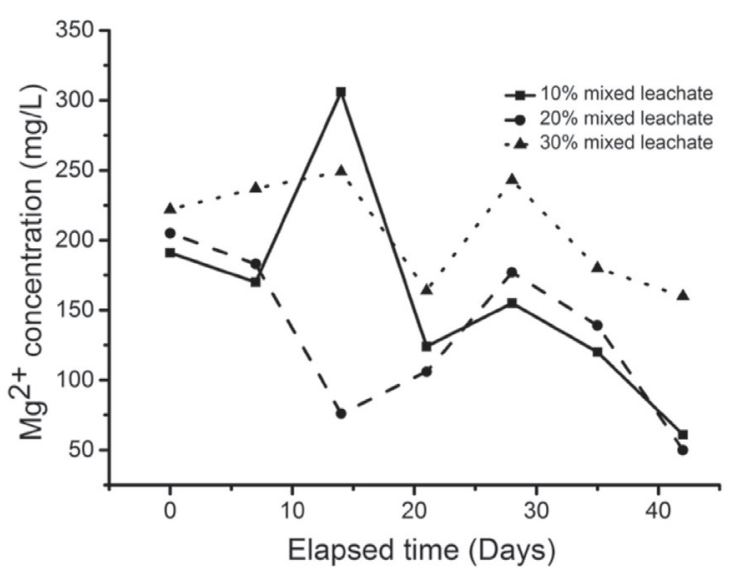

Fig. 7. Variation in $\mathrm{Mg}^{2+}$ of the mixed leachates versus elapsed time.

In the case of alkaline conditions and high $P_{\mathrm{CO} 2}$, most of the $\mathrm{Ca}^{2+}$ in the solution should be precipitated [41]. Because of the complex composition of the leachate, however, $\mathrm{Ca}^{2+}$ exists not only in ionic form but also in the form of colloids, complexes, extracellular polymers, and complex ions [42-45]. This part of $\mathrm{Ca}^{2+}$ is not easily precipitated by carbonates. Thus, there was high $\mathrm{Ca}^{2+}$ content at the end of the experiment.

\section{Analysis of $\mathrm{Mg}^{2+}$ Change in the Mixed Leachates with Elapsed Time}

In the three mixed leachates, the $\mathrm{Mg}^{2+}$ content was reduced (Fig. 7). The 10\% and 20\% mixed leachates had more $\mathrm{Mg}^{2+}$ removal, while the $30 \%$ mixed leachate had less removal.

Variations in $\mathrm{Mg}^{2+}$ content of the three mixed leachates was small, and the $\mathrm{Ca}^{2+}$ content gradually increased in the mixed leachates (Table 3). In the formation of magnesium-containing calcite, the participation of $\mathrm{Mg}^{2+}$ decreases with the increase in $\mathrm{Ca}^{2+}$ content of the leachate, and so the removal of $\mathrm{Mg}^{2+}$ in the $30 \%$ mixed leachate was less, and that in the $10 \%$ and $20 \%$ mixed leachates was more.

\section{Analysis of $\mathrm{pH}$ Change in the Mixed Leachates with Elapsed Time}

The $\mathrm{pH}$ levels of the three mixed leachates were alkaline and there was little variation at the beginning of the experiment because the old leachate content was relatively high in the mixed leachate, even if a certain volume of young leachate having a $\mathrm{pH}$ of $<7$ was added. After mixing, the leachate was still alkaline (Fig. 8). The $\mathrm{pH}$ of the three mixed leachates gradually decreased during the experiment, and the $30 \%$ mixed leachate decreased the most; however, the $\mathrm{pH}$ of the three mixed leachates remained alkaline to the end of the experiment.

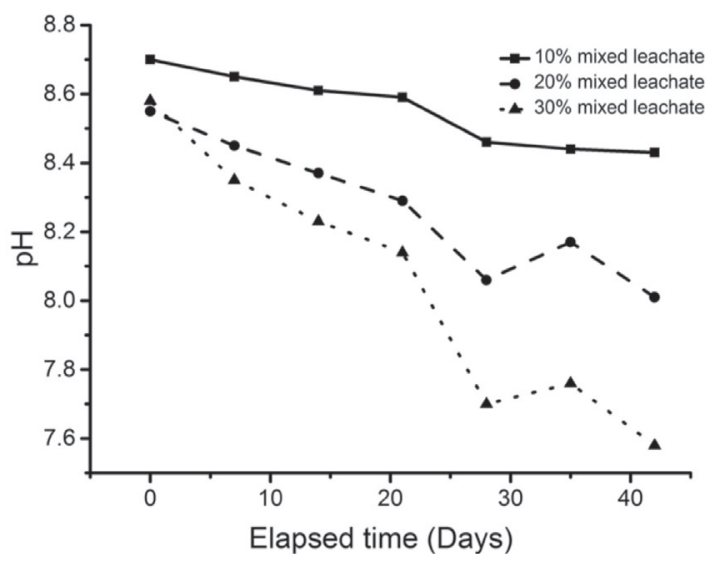

Fig. 8. Variation in $\mathrm{pH}$ of mixed leachate versus elapsed time.

Under alkaline conditions, the VFAs in the leachate mainly exist in the form of ions [46-47], and the carbonate buffer system is one of the main buffer systems. Because of the decomposition of organic matter by anaerobic microorganisms to $\mathrm{CO}_{2}(\mathrm{~g})$, the $\mathrm{CO}_{2}(\mathrm{~g})$ content of the gas phase is gradually increased, that is, the $P_{\mathrm{CO} 2}$ is increased in the closed anaerobic flask. According to Henry's Law, the $\mathrm{CO}_{2}(\mathrm{aq})$ dissolved in the leachate also gradually increases. The $\mathrm{CO}_{2}(\mathrm{aq})$ of leachate releases a large amount of $\mathrm{H}^{+}$after dissolution and ionization, so that the buffer range of the carbonate buffer system moves to a $\mathrm{pH}$ close to 7 , and the $\mathrm{pH}$ of the leachate gradually decreases.

The 30\% mixed leachate contained a higher COD (Table 3), the biodegradability was good, and the microorganisms decomposed the organic matter to generate more $\mathrm{CO}_{2}(\mathrm{~g})$, more $\mathrm{CO}_{2}(\mathrm{aq})$ dissolved in the leachate, and the $\mathrm{pH}$ decreased greatly. Since the $\mathrm{CO}_{3}{ }^{2-}$ reacts with $\mathrm{Ca}^{2+}$ and $\mathrm{Mg}^{2+}$ to form carbonate precipitates, the content of $\mathrm{CO}_{3}^{2-}$ is lowered; that is, the alkalinity of the leachate is lowered, and the $\mathrm{pH}$ of the $30 \%$ mixed leachate has a greater decrease [48-49].

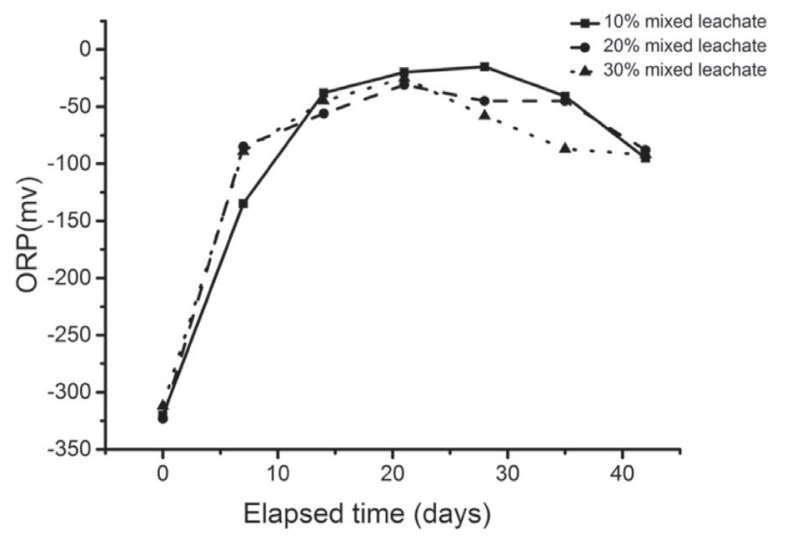

Fig. 9. Variation of ORP of mixed leachate versus elapsed time. 


\section{Analysis of ORP Change in the Mixed Leachates with Elapsed Time}

The ORP of the three mixed leachates gradually increased with time (Fig. 9). The biodegradable reducing organic matters in the leachate were oxidatively decomposed by microorganisms [50-51], and the reducibility of the leachate was gradually weakened.

\section{Conclusions}

The static anaerobic culture experiments showed that the mixed leachates had higher COD content, and biodegradability was better. The COD content of the three mixed leachates decreased greatly; COD of $10 \%$, $20 \%$, and $30 \%$ mixed leachate were reduced by $12 \%$, $38 \%$, and $24 \%$, respectively. As the content of young leachate in the mixed leachate increase, the amount of COD removed gradually increase, and microbial decomposition of COD produces more $\mathrm{CO}_{3}{ }^{2-}$.

Since the mixed leachate contains high $\mathrm{Ca}^{2+}$ and $\mathrm{Mg}^{2+}$, the $\mathrm{Ca}^{2+}$ and $\mathrm{Mg}^{2+}$ combines with $\mathrm{CO}_{3}{ }^{2-}$ to form carbonate precipitates. Analysis by $\mathrm{X}$-ray diffraction (XRD) showed that the main carbonate precipitate is magnesium-containing calcite, an isomorphous crystal. As the content of the young leachate in the mixed leachate increases, more carbonate precipitates formed, and the content of $\mathrm{Ca}^{2+}$ in the magnesium-containing calcite gradually increases, and the content of $\mathrm{Mg}^{2+}$ gradually decreases. Due to the high density of the carbonate precipitate, and the water permeability is poor, if it is deposited in the gravel drainage layer, it will cause serious clogging.

The $\mathrm{pH}$ of the three mixed leachates gradually decreased during the experimental period. As the content of the young leachate in the mixed leachate increases, the biodegradability gradually increases, and the more $\mathrm{CO}_{2}$ generated during anaerobic culture. The dissolution and ionization of $\mathrm{CO}_{2}$ will release more $\mathrm{H}^{+}$, the higher the content of young leachate in the mixed leachate, the more the $\mathrm{pH}$ was lowered.

The mixed leachate has good biodegradability, and the initial ORP was generally low at about $-300 \mathrm{mv}$. As the microorganism decomposes the biodegradable reducing organic matter in the leachate, the ORP of the leachate gradually increased and tended to be stable, indicating that most of the biodegradable reducing organic matter in the mixed leachates has been oxidized.

In summary, the mixed leachate has higher COD, $\mathrm{Ca}^{2+}, \mathrm{Mg}^{2+}$, better biodegradability, and $\mathrm{pH}>7$, so it has stronger property of forming precipitates. If such leachate is present in the gravel drainage layer due to the preferential flow of the landfill for a long time, the leachate drainage system will cause serious clogging, which will affect the safe and stable operation of the landfill. Landfill managers should optimize engineering design and strengthen daily operational management to prevent and weaken the preferential flow of leachate in the waste body.

In the operation and management of landfills, we can take the following measures to prevent and weaken preferential flow channels and leachate in the waste: to prevent large pieces of wood waste from being buried in the landfill and strictly carry out the broken bag disposal of the waste; optimize the design of vertical gas guiding wells and weaken the leachate preferential flow channel function, such as laying a certain height of the methane fermentation phase waste layer at the bottom of the well to pretreat the leachate; strengthen inspection and maintenance of the flood drainage ditch and intermediate cover film of the landfill before the rainy season to prevent rain from flowing into the waste; and for landfills operated by leachate recirculation it is necessary to strengthen the management during recirculation to prevent the preferential flow of leachate caused by uneven water distribution.

This study provided some theoretical basis for fully understanding the property of the actual leachate in the gravel layer and an in-depth discussion for preventing and controlling the clogging of the leachate in the drainage system.

\section{Acknowledgements}

This work was supported by the National Natural Science Foundation of China (No. 41602241).

\section{Conflict of Interest}

The authors declare no conflict of interest.

\section{References}

1. WANG S.W., FU G.F., ZHU X.J. Temperature influence on the permeability of clay liner for landfills. Journal of Yangzhou University, 21 (4), 17, 2018 [In Chinese].

2. TCHOBANOGLOUS G., KREITH F. Handbook of Solid Waste Management, $2^{\text {nd }}$ ed. McGraw-Hill Companies, Inc, 2002.

3. PICHAYA R., PATHUMMART C. Effects of nickel addition during different phases of solid waste decomposition. Songklanakarin Journal of Science \& Technology, 40 (4), 732, 2018.

4. ROWE R.K., YU Y. Modeling of leachate collection systems with filter separators in municipal solid waste landfills. Journal of Environmental Engineering, 139, 1042, 2013

5. KÖCHLING T., SANZ J.L., GAVAZZA S., FLORENCIO L. Analysis of microbial community structure and composition in leachates from a young landfill by 454 pyrosequencing. Applied Microbiology \& Biotechnology, 99 (13), 5657, 2015.

6. QI C.D., HUANG J., WANG B., DENG S.B., WANG Y.J., YU G. Contaminants of emerging concern in landfill leachate in China: A review. Emerging Contaminants, 1, 2018. 
7. RAMASWAMI S., BEHRENDT J., KALYANASUNDARAM S., EGGERS S., OTTERPOHL R. Experiences from an investigation on the potential of packed bed reactors for high rate nitrification of mature landfill leachates. Journal of Water Process Engineering, 22, 59, 2018.

8. ROWE R.K., YAN Y. A practical technique for estimating service life of MSW leachate collection systems. Canadian Geotechnical Journal , 50, 165, 2013.

9. YU Y., ROWE R.K. Effect of grain size on service life of MSW landfill drainage systems. Canadian Geotechnical Journal, 50, 1, 2013.

10. STIBINGER J. Approximation of clogging in a leachate collection system in municipal solid waste landfill in Osecna (Northern Bohemia, Czech Republic). Waste Management, 63, 131, 2016.

11. LIU Y.L., SUN W.X., DU B., LIU J.G. The physical clogging of the landfill leachate collection system in China: Based on filtration test and numerical modeling. International Journal of Environmental Research \& Public Health, 15, 318, 2018.

12. NIKOLOVA-KUSCU R., POWRIE W., SMALLMAN D.J. Mechanisms of clogging in granular drainage systems permeated with low organic strength leachate. Canadian Geotechnical Journal, 50, 632, 2013.

13. ILHAN F., YAZICI GUVENC S., AVSAR Y., KURT U., GONULLU, M.T. Optimization of treatment leachates from young, middle-aged and elderly landfills with bipolar membrane electrodialysis. Environmental Technology, 38, 2733, 2017.

14. REN Y., FERRAZ F., LASHKARIZADEH M., YUAN Q. Comparing young landfill leachate treatment efficiency and process stability using aerobic granular sludge and suspended growth activated sludge. Journal of Water Process Engineering, 17, 161, 2017.

15. BEAVEN R.P., HUDSON A.P., KNOX K., POWRIE W., ROBINSON J.P. Clogging of landfill tyre and aggregate drainage layers by methanogenic leachate and implications for practice. Waste Management, 33, 431, 2013.

16. NIKOLOVA-KUSCU R., POWRIE W., SMALLMAN D.J. Mechanisms of clogging in granular drainage systems permeated with low organic strength leachate. Canadian Geotechnical Journal, 50, 632, 2013.

17. NWAOKORIE K.J., BAREITHER C.A., MANTELL S.C., LECLAIRE D.J. The influence of moisture enhancement on landfill gas generation in a full-scale landfill. Waste Management, 79, 647, 2018.

18. ZHENG Q.T., ROWE R. K., FENG S.J. Design of horizontal landfill gas collection wells in nonhomogeneous landfills. Waste Management, 98, 102, 2019.

19. ROWE R.K., YU Y. Clogging of finger drain systems in MSW landfills. Waste Management, 32, 2342, 2012.

20. CAICEDO-CONCHAA D.M., SANDOVAL-COBOB J.J., WHITINGC K. An experimental study on the impact of two dimensional materials in waste disposal sites: What are the implications for engineered landfills? Sustainable Environment Research, 26, 255, 2016.

21. AHARONI I., SIEBNER H., DAHAN O. Application of vadose-zone monitoring system for real-time characterization of leachate percolation in and under a municipal landfill. Waste Management, 67, 203, 2017.

22. FENG S.J., BAI Z.B., CHEN H.X., CAO B.Y., LU S.F., CHEN Y.M. A dual-permeability hydro-biodegradation model for leachate recirculation and settlement in bioreactor landfills. Environmental Science \& Pollution Research, 25 (15), 14614, 2018.
23. ZHANG W.J., LIN M.F. Evaluating the dual porosity of landfilled municipal solid waste. Environmental Science \& Pollution Research, 26 (12), 12080, 2019.24.

24. ZHANG W.J., YUAN S.S. Characterizing preferential flow in landfilled municipal solid waste. Waste Management, 84, 20, 2019.

25. ZHANG S.L. Study on pretreatment process based on the characteristics of organic pollutant in landfill leachate. Ph.D. diss., Southwest Jiaotong University, 2010 [In Chinese].

26. RITTMANN B.E., BANASZAK J.E., COOKE A., ROWE R.K. Biogeochemical evaluation of mechanisms controlling $\mathrm{CaCO}_{3}(\mathrm{~s})$ precipitation in landfill leachatecollection systems. Journal of Environmental Engineering, 129 (8), $723,2003$.

27. VANGULCK J.F., ROWE R.K., RITTMANN B.E., COOKE A.J. Predicting biogeochemical calcium precipitation in landfill leachate collection systems. Biodegradation, 14, 331, 2003.

28. ROWE R.K., MCISAAC R. Clogging of tire shreds and gravel permeated with landfill leachate. Journal of Geotechnical and Geoenvironmental Engineering, 131, $682,2005$.

29. LOZECZNIK S., SPARLING R., CLARK S.P., VANGULCK J.F., OLESZKIEWICZ J.A. Acetate and propionate impact on the methanogenesis of landfill leachate and the reduction of clogging components. Bioresource Technology, 104, 37, 2012.

30. McIsaac R., Rowe R.K. Clogging of gravel drainage layers permeated with landfill leachate. Journal of Geotechnical \& Geoenvironmental Engineering, 133, 1026, 2007.

31. YUN J., JUNG H., CHOI H., OH K.C., JEON J.M., RYU H.W., CHO K.S. Performance evaluation of an on-site biocomplex textile as an alternative daily cover in a sanitary landfill, South Korea. Waste Management \& Research, 36 (12), 1137, 2018.

32. NAZLI Y., JAMES L.H., KEVIN B.K., EMMA H.Y. Heat management strategies for MSW landfills. Waste Management, 56, 246, 2016.

33. ZHANG T., SHI J.Y., QIAN X.D., AI Y.B. Temperature and gas pressure monitoring and leachate pumping tests in a newly filled MSW layer of a landfll. International Journal of Environmental Research, 13 (1), 19, 2019.

34. WU M.R., ZHANG R., ZHOU J., XIE X.X., YONG X.Y., YAN Z.Y., GE M.M., ZHENG T. Effect of temperature on methanogens metabolic pathway and structures of predominant bacteria. Journal of Chemical Industry and Engineering (China), 65 (5), 1602, 2014.

35. VANGULCK J.F., ROWE R.K. Influence of landfill leachate suspended solids on clog (biorock) formation. Waste Management, 24, 723, 2004.

36. KANG S., ROH Y. Biomineralization of Mg-enriched calcium carbonates by aerobic microorganisms enriched from Rhodoliths. Journal of Nanoscience \& Nanotechnology, 17 (4), 2329, 2017.

37. VANGULCK J.F., ROWE R.K., RITTMANN B.E., COOKE A.J. Predicting biogeochemical calcium precipitation in landfill leachate collection systems. Biodegradation, 14, 331, 2003.

38. BIAN X.L., LIU J.G. Influence factors in clogging of landfill leachate collection system. Advanced Materials Research, 878, 631, 2014.

39. FLEMING I.R., ROWE R.K., CULLIMORE D.R. Field observations of clogging in a landfill leachate collection system. Canadian Geotechnical Journal, 36, 685, 1999. 
40. MCISAAC R., ROWE R.K. Clogging of unsaturated gravel permeated with landfill leachate. Canadian Geotechnical Journal, 45, 1045, 2008.

41. WANG X.Y., WANG X.L., HU W.X., WAN Y., CAO J., LV C.Y., WANG R., CUI M.L. Supercritical $\mathrm{CO}_{2}$ - involved water-rock interactions at $85^{\circ} \mathrm{C}$ and partial pressures of 10-20 MPa: Sequestration and enhanced oil recovery. Energy Exploration \& Exploitation, 35 (2), 237, 2017.

42. MATURA M., ETTLER V., JEŽEK J., MIHALJEVIČ M., ŠEBEK O., SÝKORA V., KLEMENTOVÁ M. Association of trace elements with colloidal fractions in leachates from closed and active municipal solid waste landfills. Journal of Hazardous Materials, 183 (1-3), 541, 2010.

43. MATURA M., ETTLER V., KLEMENTOVÁ M. Transmission electron microscopy investigation of colloids and particles from landfill leachates. Waste Management \& Research, 30 (5), 530, 2011.

44. XIA Y., HE P.J., PU H.X., LÜ F., SHAO L.M., ZHANG $H$. Inhibitory effect of high calcium concentration on municipal solid waste leachate treatment by the activated sludge process. Waste Management \& Research, 35 (5), 508, 2017.

45. CHENG W., QUAN X.J., HUANG X.X., CHENG C., YANG L., CHENG Z.L. Enhancement of micro-filtration performance for biologically-treated leachate from municipal solid waste by ozonation in a micro bubble reactor. Separation \& Purification Technology, 207, 535, 2018.

46. JIANG Y., DENNEHY C., LAWLOR P.G., HU Z., YANG Q., MCCARTHY G., TAN S.P., ZHAN X.M., GARDINER
G.E. Inactivation of Salmonella during dry co-digestion of food waste and pig manure. Waste Management, 82, 231, 2018.

47. RIUNGU J., RONTELTAP M., VAN LIER J.B. Buildup and impact of volatile fatty acids on $E$. coli and $A$. lumbricoides during co-digestion of urine diverting dehydrating toilet (UDDT-F) faeces. Journal of Environmental Management, 215, 22, 2018.

48. LOZECZNIK S., OLESZKIEWICZ J.A., CLARK S.P., SPARLING R., VANGULCK J.F. Effects of turbulence and temperature on leachate chemistry. Journal of the Environmental Engineering, 138, 562, 2012.

49. SIPPO J.Z., MAHER D.T., TAIT D.R., HOLLOWAY C., SANTOS I.R. Are mangroves drivers or buffers of coastal acidification? Insights from alkalinity and dissolved inorganic carbon export estimates across a latitudinal transect. Global Biogeochemical Cycles, 30 (5), 753, 2016.

50. ANFRUNS A., GABARRÓ J., GONZALEZ-OLMOS R., PUIG S., BALAGUER M.D., COLPRIM J. Coupling anammox and advanced oxidation-based technologies for mature landfill leachate treatment. Journal of Hazardous Materials, 258-259, 27, 2013.

51. DA COSTA F.M., DAFLON S.D.A., BILA D.M., DA FONSECA F.V., CAMPOS J.C. Evaluation of the biodegradability and toxicity of landfill leachates after pretreatment using advanced oxidative processes. Waste Management, 76, 606, 2018. 
